\title{
Greener Pathways for Energy-Intensive Commodity Chemicals: Opportunities and Challenges
}

\author{
Yuan Yao $^{1}$, Diane Graziano ${ }^{2}$, Matthew Riddle ${ }^{2}$, Joe Cresko ${ }^{3}$, and Eric Masanet ${ }^{1,4^{*}}$ \\ ${ }^{1}$ Department of Chemical \& Biological Engineering, Northwestern University, 2145 Sheridan \\ Road, Evanston, Illinois, USA 60201 \\ ${ }^{2}$ Decision and Information Sciences Division, Argonne National Laboratory, 9700 South Cass \\ Avenue, Argonne, Illinois, USA 60439 \\ ${ }^{3}$ Advanced Manufacturing Office, United States Department of Energy, 1000 Independence \\ Avenue, SW, Washington, DC, USA 20585 \\ ${ }^{4}$ Department of Mechanical Engineering, Northwestern University, 2145 Sheridan Road, \\ Evanston, Illinois, USA 60201 \\ *eric.masanet@northwestern.edu
}

\begin{abstract}
The chemical industry is poised for significant growth and investment, which presents an opportunity for adoption of greener chemical technologies. This article reviews available and emerging technologies for reducing the fossil fuel demand associated with the ammonia, ethylene, methanol, propylene, and benzene, toluene, and xylenes (BTX) industries. These few energyintensive commodity chemicals (EICCs) account for around half of the energy use and greenhouse gas (GHG) emissions of the global chemical industry. Available data are harmonized to characterize potential energy use and GHG emissions savings, while technical and economic barriers to adoption are discussed. This information sheds light on the status of future technological options for reducing the impacts of the chemicals industry, and provides quantitative data to industry analysts and policy makers seeking a greater understanding of such options for EICCs.
\end{abstract}

\section{Introduction}

As economies recover from the 2008 recession, demand for chemicals is increasing. The global chemical industry is projected to grow by $4.1 \%$ in 2015 [1] with continued growth over the coming decades [2]. In the United States, shale gas has improved the competitiveness of the chemical industry and has spurred increased capital investment, production, and exports [3]. By 2018, the American Chemistry Council forecasts capital spending to reach $\$ 61$ billion in the United States and $\$ 618$ billion globally [1].

As new plants are constructed and existing plants are expanded and upgraded, opportunities arise for adoption of greener technologies, including more energy efficient equipment, greener solvents [4,5], improved reactions and catalysts [6,7], alternative feedstocks [8,9], and process intensification [10-12], to name a few. Such technologies align with the Twelve Principles of 
Green Chemistry [13], which fall broadly into two categories: (1) energy and materials efficiency; and (2) human and ecological health protection.

Greener technology options that reduce fossil fuel inputs for process energy and/or feedstocks are particularly important moving forward. Chemical production is the world's largest industrial energy consumer, with a 30\% share of global industrial energy use (including feedstocks) [14]. Reducing fossil fuel inputs can decelerate resource depletion, reduce air pollution, and mitigate environmental stresses related to fossil fuel extraction, transport, and use [15] — benefits that align well with the Twelve Principles. Furthermore, the chemical industry is the world's third largest source of industrial greenhouse gas (GHG) emissions, due largely to fossil fuel combustion for process energy [16]. Therefore, reducing fossil fuel inputs is also a critical climate change risk mitigation strategy, both for the industry and for society [17].

This article reviews available and emerging technologies for reducing fossil fuel use associated with ammonia, ethylene, methanol, propylene, and benzene, toluene, and xylenes (BTX). As indicated by Figure 1, these few energy-intensive commodity chemicals (EICCs) account for around half of the energy use and GHG emissions of the global chemical industry [18]. Specifically, this article harmonizes recent data on the performance and barriers associated with more energy-efficient production processes, alternative feedstocks, and substitutes for these EICCs and their derivatives.
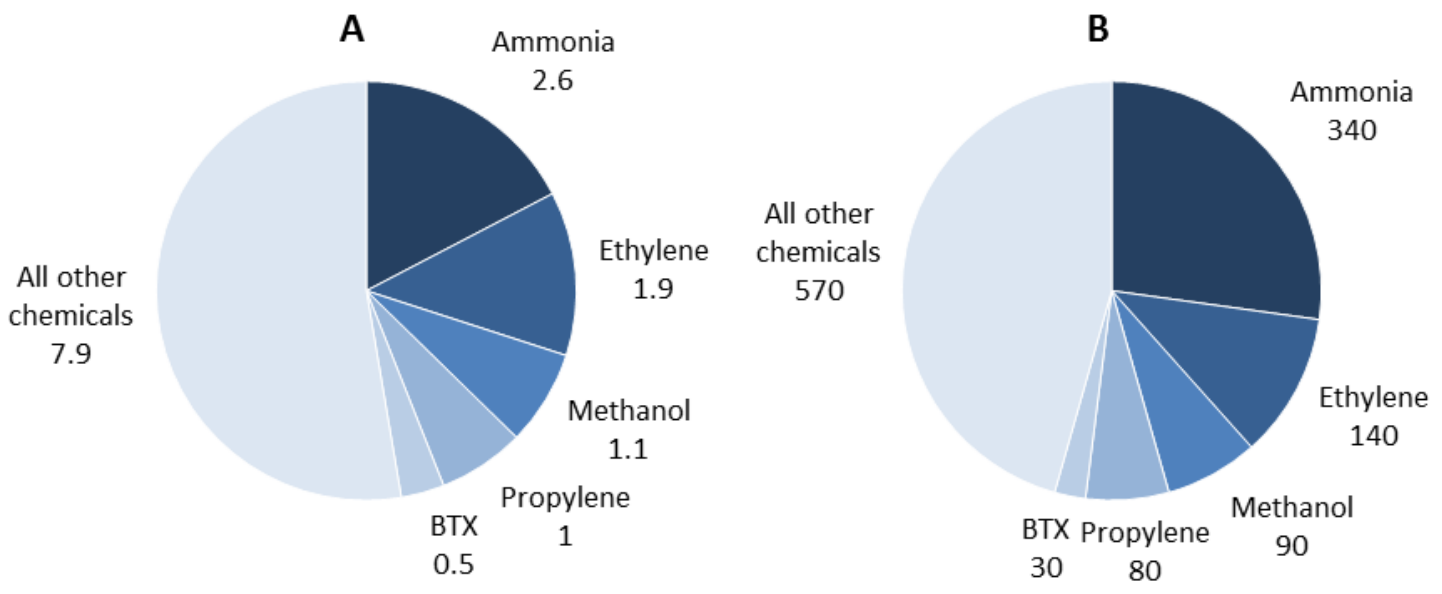

Figure 1. International Energy Agency estimates of the (A) energy consumption (in EJ/year) and (B) $\mathrm{GHG}$ emissions (in $\mathrm{MtCO}_{2}$-eq/year) of the global chemical industry in 2010 [18].

While this summary is not comprehensive of all possible technology improvements, it focuses on pathways for which recent and credible data exist in the literature related to potential energy and GHG emissions reductions and implementation barriers. Section 2 includes pathways that reduce process energy demand within EICC plants, while Section 3 includes pathways that can reduce or eliminate the need for fossil fuel feedstocks for EICCs and their derivatives. 


\section{Energy-Efficient Pathways from Fossil Fuel Feedstocks}

Production of EICCs is predominantly based on fossil fuel feedstocks, which will continue for the foreseeable future. Most EICCs are manufactured in highly integrated, multi-chemical plants that have steadily improved energy efficiencies over time, as evidenced by a $39 \%$ reduction in the energy intensity of the U.S. chemical sector between 1994 and 2007 [18]. Common improvements include process heat integration, advanced controls, and best practice technologies for steam, pumps, motors, and other plant systems [14,19,20]. Still, chemical plant audits regularly identify technology options for even greater efficiency [21,22], and the state-of-the-art for many processes continues to evolve [20]. Table 1 summarizes recent performance data on several energy efficient process technologies for producing ethylene, propylene, and ammonia from current feedstocks, which can reduce direct fossil fuel inputs and GHG emissions compared to prevailing process technologies.

\subsection{Ethylene and propylene}

These two light olefins are currently produced by steam cracking of natural gas liquids (NGL) and naphtha or as byproducts of the petroleum refining process [14]. The technology data in Table 1 indicate a wide range in potential onsite energy intensity reductions, as well as suitability for increasingly competitive natural gas feedstocks [3].

The five process intensification technologies for ethylene in Table 1 are listed in order of decreasing technological maturity, and all but one are still at the lab scale. Catalyst-assisted production of olefins $\left(\mathrm{CAMOL}^{\mathrm{TM}}\right)[23]$ is currently being demonstrated at the pilot scale, with estimated energy intensity reductions attributable to reduced decoking energy use in the furnace coils of the ethane cracker. No data are available on the expected investment costs of CAMOLcoated coils. However, given that ethylene production costs are dominated by the cost of input fuels [3], the substantial reported energy savings are likely to justify the incremental costs for coated coils. Additional pilot tests and verified performance and cost data should lead to a commercialized technology in the next several years.

The hybrid membrane/distillation process has been researched for many years, but has yet to see commercial adoption due to barriers related to application design optimization [24] and reliable prediction of membrane module performance [25]. Available economic analyses indicate significant investment savings of 54-61\% compared to a conventional C2-splitter and 11-36\% compared to a C3-splitter [26]. Similarly, Compact Membrane Systems reported a return on investment of up to $67 \%$ with a payback time of 1.3 years for a hybrid system [27]. However, more research efforts are needed to address the aforementioned process design barriers, and pilot applications are necessary to verify cost and energy savings to bring this technology closer to commercialization.

The advantage of microchannel process technology (MPT) lies in its improved heat and mass transfer performance compared to conventional reactors and distillation units. Currently, its high capital cost, which is mainly attributable to its manufacturing complexity, serves as a major barrier to commercialization and widespread adoption by olefin plants. Given its modularity and flexibility, however, it may find a responsive early market in small scale distillation facilities if capital costs can be lowered through manufacturing process cost reductions. 
Hollow fibers as distillation packing materials deliver smaller estimated energy intensity reductions compared to the preceding options, so low investment costs will be critical to the success of this lab-scale technology. Recent data suggest that hollow fibers can provide stable and efficient olefin/paraffin distillation with high capacities [28]. However, several engineering barriers must be overcome before commercialization, including identification of robust, durable, and economical polymeric fibers and challenges related to efficient scaled-up process design [28]. A future scale-up test will be conducted by Chevron [29], which may help to accelerate the commercialization process.

Alternative chemical pathways being investigated for the production of ethylene include: (1) ethane oxidative dehydrogenation (EOD) [30,31]; (2) oxidative coupling of methane (OCM)[32]; and (3) methanol to olefins (MTO)[32,33]. At the lab scale, EOD catalysts have improved ethylene yields to $45-75 \%$ [34], which is comparable to conventional technologies. Patent data for EOD technology suggest a lower investment cost for separation/recovery, due to reduced product mix complexity compared to conventional steam cracking [35]. While other cost data are not reported, its complex reactor design [36] and intensive catalyst usage [31] may lead to high system costs. Therefore, the future commercialization of this technology likely hinges on a more efficient and economical reactor and more durable and stable catalysts.

OCM and MTO are absent from Table 1 due to lack of conclusive data on process energy intensities compared to conventional cracking. However, one OCM pilot facility is planned in La Porte, Texas for 2015, which will contribute to its development and feasibility [REF]. MTO is commercialized and viable in regions where methane is less costly than steam cracking feedstock, but analysis data suggest that MTO has a higher onsite energy intensity than conventional pathways [18,32]. However, if coupled with renewable methanol or renewable energy sources, MTO holds great promise for greener ethylene production.

Propane dehydrogenation (PDH) use is growing rapidly due to the recent shale gas boom, with new PDH plants announced that will range in capacity from 600-750 thousand tonnes ( $t$ ) of propylene per year [30,37]. Furthermore, the production cost of PDH is $\$ 885 /$ ton, which is highly favorable compared to the average U.S. propylene price of $\$ 1428 /$ ton in 2012 [38]. Thus, PDH delivers substantial reductions in both energy intensity and production costs, which makes it an exemplary greener chemistry technology option, especially as propylene demand and propane supply (due to shale gas) increase moving forward. Additionally, H2 produced by PDH offer additional revenue if markets are nearby.

\subsection{Ammonia}

Ammonia is currently produced by the Haber-Bosch [39] process using methane feedstock. The energy efficient technology options listed for ammonia in Table 1 include four commercial technologies, whose adoption is driven by production characteristics and investment criteria that can vary across plants, and one lab-scale technology. All technologies were included here to illustrate the potential energy savings associated with state-of-the-art equipment upgrades at ammonia plants compared to conventional ammonia synthesis processes. Furthermore, the energy intensity reductions in Table 1 represent the most recent data from the literature harmonized to a consistent comparison basis, which underscores the range of efficiency 
improvements achievable through different process equipment selections. In particular, the use of packaged designs can lead to energy intensity improvements compared to conventional systems, and such packages can be used to replace existing process equipment or in new lines for expanded production.

The lab-scale ammonia production technology demonstrates that significant energy efficiency improvements might still be had for processes as mature as Haber-Bosch, and for which a number of commercial efficiency options already exist [40]. This process intensification technology leads to estimated energy intensity reductions substantially greater than the commercialized ammonia process technologies. Preliminary cost data suggest slightly lower capital costs than other options as well [40]. However, pilot test data at larger scales are needed to verify the energy savings and cost competitiveness of this technology before its commercialization potential can be assessed.

\subsection{Methanol and BTX}

For methanol and BTX, a particularly promising pathway is from direct conversion of methane. While no energy savings data have been reported for direct conversion pathways, energy savings are expected at production scales due the greatly simplified process inherent in direct conversion routes. Therefore, much research into direct conversion of methane is underway, which may lead to viable process technologies in the near future with continued effort.

Several direct conversion pathways have been reported for methanol [41], including gas-phase catalytic partial oxidation [42]; liquid-phase catalytic oxidation [43,44]; and water-based biological oxidation. The latter approach attempts direct conversion of methane to methanol via methane monooxygenases enzymes at ambient temperature. Research on the direct conversion to methanol derivatives, such as formaldehyde [45,46] and acetic acid [47]), has also been reported. For BTX, direct non-oxidative conversion of methane to aromatics $[41,48]$ has been demonstrated at the lab scale. 


\begin{tabular}{|c|c|c|c|c|c|}
\hline Chemicals & Technology & Feedstock & Process Description & $\begin{array}{l}\text { Development } \\
\text { Stage }\end{array}$ & $\begin{array}{l}\text { On-site Energy } \\
\text { Reduction Compared } \\
\text { to Reference } \\
\text { Technology }{ }^{\mathrm{a}} \text { (GJ/t } \\
\text { product) }\end{array}$ \\
\hline \multirow[t]{5}{*}{ Ethylene } & $\begin{array}{l}\text { Catalyst-assisted production of olefins } \\
\left(\mathrm{CAMOL}^{\mathrm{TM}}\right)[23]\end{array}$ & NGL & Cracker catalyst coating reduces coke deposits & Pilot plant test & $\begin{array}{c}1-2 \\
(6 \%-10 \%)\end{array}$ \\
\hline & $\begin{array}{l}\text { Membrane/distillation hybrid process } \\
\text { [27] }\end{array}$ & NGL & $\begin{array}{l}\text { A technology integrating membrane and } \\
\text { distillation }\end{array}$ & Lab scale & $\begin{array}{c}1-1.7 \\
(5 \%-9 \%)\end{array}$ \\
\hline & $\begin{array}{l}\text { Microchannel process technology } \\
\text { (MPT) distillation[49] }\end{array}$ & NGL & $\begin{array}{l}\text { A novel process which combines heat transfer } \\
\text { and gas separation into one unit }\end{array}$ & Lab scale & $\begin{array}{c}0.6 \\
\text { (3\% saving for } \\
\text { entire process, } \\
16 \% \text { saving for } \\
\text { distillation units) }^{\mathrm{b}}\end{array}$ \\
\hline & $\begin{array}{l}\text { Enhanced separation efficiency in } \\
\text { olefin/paraffin distillation through } \\
\text { hollow fiber technology[50] }\end{array}$ & NGL & $\begin{array}{l}\text { Replacement of conventional packing materials } \\
\text { with hollow fibers }\end{array}$ & Lab scale & $\begin{array}{c}0.4 \\
\text { (2\% saving for } \\
\text { entire process, } \\
11 \% \text { saving for } \\
\text { distillation units) } \\
\text { b }\end{array}$ \\
\hline & $\begin{array}{l}\text { Ethane oxidative } \\
\text { dehydrogenation }[30,31]\end{array}$ & Ethane & Ethane to ethylene through catalytic reaction & Lab scale & $\begin{array}{c}6.7-10.3 \\
(35 \%-54 \%)\end{array}$ \\
\hline Propylene & Propane dehydrogenation $(\mathrm{PDH})[30,37]$ & Propane & $\begin{array}{l}\text { Directly conversion of propane to propylene } \\
\text { and hydrogen }\end{array}$ & Commercial & $\begin{array}{c}5-7 \\
(40 \%-50 \%) \\
\end{array}$ \\
\hline \multirow[t]{5}{*}{ Ammonia } & $\begin{array}{l}\text { Topsøe low-energy ammonia } \\
\text { technology[51] }\end{array}$ & Methane & $\begin{array}{l}\text { Package includes Haldor Topsøe heat } \\
\text { exchanger, better catalyst design, and } \\
\text { proprietary converter design }\end{array}$ & Commercial & $\begin{array}{c}6-8 \\
(17 \%-22 \%)\end{array}$ \\
\hline & KBR KAAPplus[39] & Methane & $\begin{array}{l}\text { Package includes ATR parallel with exchanger } \\
\text { reformer, ruthenium catalyst, clean and dry } \\
\text { make-up gas to the synthesis loop }\end{array}$ & Commercial & $\begin{array}{c}8.6 \\
(24 \%)\end{array}$ \\
\hline & ATR (autothermal reformer) $[52,53]$ & Methane & $\begin{array}{l}\text { Partial oxidation and steam reforming are } \\
\text { highly integrated in one reactor, which is more } \\
\text { efficient than a pure steam reforming process }\end{array}$ & Commercial & $\begin{array}{c}7.2 \\
(20 \%)\end{array}$ \\
\hline & Reforming exchanger[54] & Methane & $\begin{array}{l}\text { Improved heat recovery in primary reformer } \\
\text { section }\end{array}$ & Commercial & $\begin{array}{l}\leq 2.5 \\
(\leq 7 \%)\end{array}$ \\
\hline & $\begin{array}{l}\text { Process integration of ammonia reactor } \\
\text { and ammonia PSA recovery }[40,55]\end{array}$ & Methane & $\begin{array}{l}\text { Process integration of ammonia reactor and } \\
\text { ammonia pressure swing adsorption }\end{array}$ & Lab-scale & $\begin{array}{c}14-18 \\
(40 \%-50 \%)\end{array}$ \\
\hline
\end{tabular}

${ }^{\mathrm{a}}$ The reference technology for ethylene is ethane cracking process (19 GJ/t ethylene [30,56]); for propylene is naphtha cracking process (15 GJ/t propylene[14]), and for anhmonia is ammonia synthesis process (36 GJ/t ammonia[14,57]).[27] 


\section{Alternative Feedstock Pathways}

A large share of fossil fuel use for chemicals (e.g., around 50\% in the United States [58]) is attributable to feedstocks. Research on alternative feedstocks is vibrant, primarily due to rapidly growing demand for "green" chemical products. Quantifying the environmental implications of alternative feedstocks requires a life-cycle assessment (LCA) approach that considers mass and energy inputs and related environmental impacts across the entire product life cycle [59].

This section reviews emerging technologies as well as recently available (but sparse) data from the LCA literature on the use of biomass and byproduct $\mathrm{CO}_{2}$ as chemical feedstocks for EICCs, their derivatives, and substitute products. While alternative feedstock pathways for EICC derivatives and substitutes will not directly affect the energy/carbon intensity of conventional EICC production, they could lead to reductions in the energy use and GHG emissions of the global chemical sector due to decreased demand for conventional EICCs. Table 2 summarizes the available data on life-cycle savings and current production costs, expressed relative to conventional fossil fuel feedstock pathways for ease of comparison.

\subsection{Biomass}

As illustrated in Figure 2, biomass can be converted into chemicals through either biochemical or thermo-chemical pathways [60]. The former approach uses biocatalysts, enzymes, bacteria, or other microorganisms to convert biomass to fuels and chemicals[61], while the latter uses heat to break down biomass into hydrocarbons that are further processed into EICCs and their derivatives.

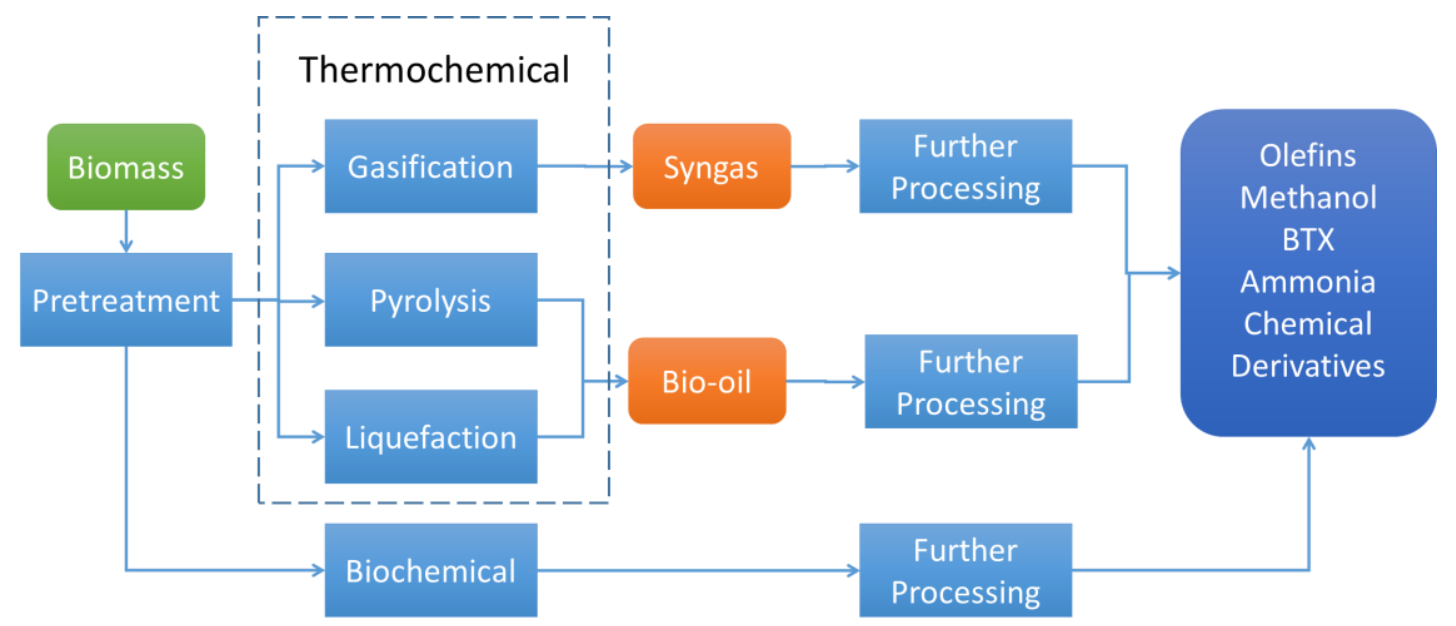

Figure 2 Biomass to chemicals pathways[60]

Most commercialized applications for biomass feedstocks in the literature are limited to high value chemicals and polymers, and at production scales much smaller than conventional EICC plants [62]. One exception is bioethylene, for which plants in Brazil and India represent about $0.3 \%$ of global ethylene capacity using catalytic dehydration of bioethanol from sugarcane[63]. Future development of biorefineries that integrate both biofuel and bio-based chemical production could be transformational in advancing these pathways due to co-product synergies and improved economies of scale [63]. The reader is referred to [62] for an excellent review of 
the commercial status and outlook for the production of EICC or their derivatives from biomass feedstocks.

The seven biomass feedstock pathways summarized in Table 2 include commercialized and pilot scale technology pathways for ethylene and derivatives or substitutes for ethylene, propylene, and BTX. Included in these pathways are diverse sources such as agricultural residues, plant oils, and commodity crops, which underscores the broad diversity of emerging biomass feedstock applications. Also included are ranges of costs estimates from the available literature, expressed relative to costs of conventional fossil-fuel-based chemical production.

The identified data in Table 2 suggest that substantial life-cycle energy and GHG emissions savings might be achievable through the adoption of biomass feedstock pathways for EICCs and their substitutes and derivatives. In most cases, savings are primarily attributable to less energyintensive process pathways and carbon cycling benefits of biomass use. However, it must be noted that, as with all LCAs, significant uncertainties are associated with the source data. For example, previous LCA studies indicate large uncertainties [64-66] on results for biofuels due to the complexities of their life-cycle systems. In particular, the identified range of results for bio PHA suggest that life-cycle savings are not guaranteed for all system variations $[8,67]$. Still, compared to Table 1, the data in Table 2 suggest that biomass feedstocks pathways may hold promise for reducing the energy footprint (GJ/t) of EICC production beyond what may be achieved through improved process efficiencies in prevailing fossil fuel feedstock pathways alone.

Among all bio-based chemicals listed in Table 2, bio-based PLA is the only chemical whose cost benefits has been validated through its application in packaging, coatings, printing and medical implants [68]. Bio-based adipic acid is very close to commercialization and is reportedly cost competitive.[69]. While no verifiable cost data could be found for bio-based PET, it is expected to be reasonably cost-competitive compared to petroleum-based PET due to its adoption in commercial soft drink bottling applications $[68,70]$.

In addition to technology immaturity and challenges with scaling up to large production quantities, feedstock and processing costs are another major risk factor associated with bio-based chemicals. For example, the cost of bio-ethylene production depends heavily on its region, with higher costs presently reported in the United States ( $\$ 2,000 /$ from corn) and Europe $(\$ 2,600 / \mathrm{t}$ from sugar beets) and substantially lower costs reported in Brazil and India $(\$ 1,200 / t)[71]$. To overcome these significant cost barriers, substantial improvements will be needed throughout the value chain, including increased yields and greater logistical efficiencies for feedstocks, improved efficiencies and cost reductions in conversion processes, and more value placed on bio-based chemicals through increased consumer demand, greater public subsidies to the industry, or both.

\subsection{Byproduct carbon dioxide}

While $\mathrm{CO}_{2}$ is an established feedstock in chemicals production (e.g., for urea and salicyclic acid), there is increasing focus on utilization of waste $\mathrm{CO}_{2}$ as a strategy for GHG emissions mitigation. Unlike $\mathrm{CO}_{2}$ that is purposely-produced for chemicals, waste $\mathrm{CO}_{2}$ refers to $\mathrm{CO}_{2}$ that is currently discharged to the atmosphere as a combustion byproduct (e.g., from boilers, furnaces, or electric power plants). The reader is referred to [72] for a comprehensive review of chemical pathways for recovered waste $\mathrm{CO}_{2}$, which range from hydrogenation for the production of methanol 
(existing) to electrocatalytic or photocatalytic reduction of $\mathrm{CO}_{2}$ for the production of olefins (exploratory).

Table 2 includes LCA data for producing methanol from recovered waste $\mathrm{CO}_{2}$ and hydrogen produced using renewable power, which are situations that can lead to substantial life-cycle GHG emissions savings [72,73]. The high costs of such processes, which are mostly attributable to hydrogen production, currently present a major barrier to wider adoption. If a cheaper route of hydrogen supply is available (e.g., hydrogen produced as a byproduct from PDH plants, as discussed above), the cost of using waste $\mathrm{CO} 2$ for methanol might be reduced significantly.

Still, the use of renewable resources is critical as the economic and environmental benefits of these methanol pathways would be offset by energy intensive $\mathrm{H}_{2}$ production and $\mathrm{CO}_{2}$ purification processes. The identified data shed light on one example of a shift to a "methanol economy," which has been espoused by thought leaders to promote carbon recycling by capitalizing on the utility of methanol as both a fuel and a chemical building block [73].

\section{Summary}

The data summarized here shed light on the potential of available and emerging technologies for reducing fossil fuel dependencies associated with EICCs and their substitutes and derivatives. For available and mature technologies, barriers are often related to limited budgets for capital investments - even when life-cycle costs are favorable - but increased plans for production expansions over the next few years might help overcome these barriers for many plants.

Additional barriers include risk aversion, sunk capital costs in existing equipment, and knowledge barriers related to efficient technology options and their expected performance [74]. For the emerging technologies and pathways, much research and investment effort is still needed to improve both technical performance and cost competitiveness, and accelerated pilots and demonstrations will be critical for commercialization and market uptake in the near term.

While this review characterized technologies based on available literature data, there are certainly more emerging greener chemistry technologies for EICCs at the lab and pilot scales for which performance data do not exist in the public domain. Furthermore, uncertainties associated with published performance data and analyses limited the scope of this article to technologies for which only substantial energy use and emissions reductions are expected. There is a pressing need for more credible analysis data on such technologies, so that chemicals industry engineers, energy analysts, and policy makers can identify and assess future technology options as society seeks to minimize its environmental footprint. That said, the information presented here sheds some credible light on the status of future technological options for reducing the impacts of the chemicals industry, and provides quantitative data to industry analysts and policy makers seeking a greater understanding of such options for EICCs for deeper analyses of their own. 


\begin{tabular}{|c|c|c|c|c|c|c|}
\hline $\begin{array}{l}\text { Chemical } \\
\text { [References] }\end{array}$ & $\begin{array}{l}\text { Conventional } \\
\text { Process }\end{array}$ & Feedstock $^{a}$ & Conversion pathway & $\begin{array}{l}\text { Life Cycle Energy } \\
\text { Reduction } \\
\text { GJ /t product }(\%)\end{array}$ & $\begin{array}{l}\text { Life Cycle GHG } \\
\text { Reduction } \\
\text { t } \mathrm{CO}_{2} \text {-eq } / \mathrm{t} \\
\text { product }(\%)\end{array}$ & $\begin{array}{l}\text { Developmen } \\
\text { Stage }\end{array}$ \\
\hline $\begin{array}{l}\text { Bio adipic } \\
\text { acid[69,75] } \\
\text { (benzene derivative) } \\
\end{array}$ & $\begin{array}{l}\text { Petroleum-based, } \\
\text { benzene building } \\
\text { block }\end{array}$ & Glucose from sugar beet & $\begin{array}{l}\text { Bio-chemical \& } \\
\text { Thermal-chemical }\end{array}$ & $\begin{array}{l}30.4-58.9 \mathrm{GJ} / \mathrm{t} \\
(29 \%-57 \%)\end{array}$ & $\begin{array}{l}9.8-17.4 \mathrm{tCO}_{2}-\mathrm{eq} / \mathrm{t} \\
(\mathrm{NA})\end{array}$ & $\begin{array}{l}\text { Pilot plant, } \\
\text { commercializ } \\
\text { in } 1 \sim 2 \text { years }\end{array}$ \\
\hline $\begin{array}{l}\text { Bio polylactic acid } \\
\text { PLA[76,77] } \\
\text { (substitute) }\end{array}$ & $\begin{array}{l}50 \% \text { PE, 50\% } \\
\text { polypropylene } \\
\text { (PP) from } \\
\text { ethylene, } \\
\text { propylene (PLA } \\
\text { replace PP and PE } \\
\text { as plastics) }\end{array}$ & Corn starch & Bio-chemical & $\begin{array}{l}22-50 \mathrm{GJ} / \mathrm{t} \\
(29 \%-66 \%)\end{array}$ & $\begin{array}{l}0.8-3.0 \mathrm{tCO}_{2}-\mathrm{eq} / \mathrm{t} \\
(17 \%-63 \%)\end{array}$ & Commerciali \\
\hline $\begin{array}{l}\text { Bio Polyethylene } \\
\text { terephthalate } \\
\text { PET[78] } \\
\text { (ethylene, xylene } \\
\text { derivative) }\end{array}$ & $\begin{array}{l}\text { Petroleum based } \\
\text { PET produced } \\
\text { from ethylene } \\
\text { glycol and purified } \\
\text { terephthalic } \\
\text { acid/dimethyl } \\
\text { terephthalate }\end{array}$ & Maize and sugarcane & $\begin{array}{l}\text { Bio-chemical \& } \\
\text { thermo-chemical }\end{array}$ & $\begin{array}{l}13-22 \mathrm{GJ} / \mathrm{t} \\
(24 \%-32 \%)\end{array}$ & $\begin{array}{l}1-2 \mathrm{tCO}_{2}-\mathrm{eq} / \mathrm{t} \\
\mathrm{PET} \\
(41 \%-43 \%)\end{array}$ & Commerciali \\
\hline Bio ethylene[67,71] & $\begin{array}{l}\text { steam cracking of } \\
\text { NGL/naphtha/gas } \\
\text { oil }\end{array}$ & $\begin{array}{l}\text { Sugarcane, lignocelluloses, } \\
\text { maize starch }\end{array}$ & Bio-chemical & $40 \%-100 \%$ & $40 \%$ & Commerciali \\
\hline $\begin{array}{l}\text { Bio Polyethylene[8] } \\
\text { (ethylene derivative) }\end{array}$ & $\begin{array}{l}\text { Polyethylene (PE) } \\
\text { from ethylene }\end{array}$ & Corn starch or sugar cane & Bio-chemical & $\begin{array}{l}29.3-67.6 \mathrm{GJ} / \mathrm{t} \\
(40 \%-88 \%)\end{array}$ & $\begin{array}{l}2.1-4.2 \mathrm{tCO}_{2}-\mathrm{eq} / \mathrm{t} \\
(120 \%-200 \%)\end{array}$ & Commerciali \\
\hline $\begin{array}{l}\text { Bio polyhydroxyalk- } \\
\text { anoate } \\
\text { (PHA) }[8,67,77] \\
\text { (substitute) }\end{array}$ & $\begin{array}{l}\text { Polyethylene (PE) } \\
\text { from ethylene } \\
\text { (PHA replace PE } \\
\text { as biodegradable } \\
\text { plastics) }\end{array}$ & $\begin{array}{l}\text { Agriculture residues, corn } \\
\text { starch, sugar cane, } \\
\text { lignocelluloses }\end{array}$ & Bio-chemical & $\begin{array}{l}-35-58.9 \mathrm{GJ} / \mathrm{t} \\
(-47 \%-77 \%)\end{array}$ & $\begin{array}{l}-2.6-2.8 \mathrm{tCO}_{2}-\mathrm{eq} / \mathrm{t} \\
(-160 \%-175 \%)^{\mathrm{b}}\end{array}$ & Commerciali \\
\hline
\end{tabular}




\begin{tabular}{|c|c|c|c|c|c|c|}
\hline Methanol[79] & Methane & $\begin{array}{l}\mathrm{CO}_{2} \text { captured from power } \\
\text { plant; } \mathrm{CO} \text { generated by } \\
\text { thermochemical splitting of } \\
\mathrm{CO}_{2} \text { using solar thermal } \\
\text { energy; } \mathrm{H}_{2} \text { generated by water } \\
\text { gas shift of } \mathrm{H}_{2} \mathrm{O} \text { and } \mathrm{CO}\end{array}$ & $\begin{array}{l}\text { Methanol synthesis } \\
\text { from } \mathrm{CO} / \mathrm{H}_{2}\end{array}$ & $\begin{array}{l}10 \mathrm{kWh} / \mathrm{kg} \\
(98 \%)\end{array}$ & $\begin{array}{l}2.4 \mathrm{tCO}_{2} \text {-eq/t } \\
(350 \%)^{\mathrm{c}}\end{array}$ & Commerciali \\
\hline Methanol[80] & Methane & $\begin{array}{l}\mathrm{CO}_{2} \text { captured from power } \\
\text { plant; } \mathrm{H}_{2} \text { generated by } \\
\text { electrolysis supplied by wind } \\
\text { farm }\end{array}$ & $\begin{array}{l}\text { Direct methanol } \\
\text { synthesis from } \\
\mathrm{CO} 2 / \mathrm{H} 2\end{array}$ & $\mathrm{NA}$ & $\begin{array}{l}1.1 \mathrm{CO}_{2}-\mathrm{eq} / \mathrm{t} \\
(59 \%)\end{array}$ & \\
\hline
\end{tabular}

${ }^{\mathrm{a}}$ As reported in the source study.

${ }^{\mathrm{b}}$ Negative values indicate emerging pathway is more energy and/or GHG intensive than the conventional pathway; percent savings greater than $100 \%$ are attributable to avoided emissions

${ }^{c}$ Large GHG emissions reductions are attributable to carbon capture and renewable energy 


\section{Acknowledgements}

This work is supported by DOE under contract number DE - AC02 - 06CH11357. The data and views expressed in this paper are those of the authors and are not endorsed by the U.S.

Department of Energy or the United States government.

\section{References}

1. American Chemistry Council: Year-end 2013 chemical industry situation and outlook. Edited by. Washington, DC, USA: American Chemistry Council 2013.

2. Valencia RC: The future of the chemical industry by 2050: Wiley-VCH; 2013.

3. Coopers PW: Shale gas: Reshaping the US chemicals industry. 2012.

4. Simon M-O, Li C-J: Green chemistry oriented organic synthesis in water. Chemical Society Reviews 2012, 41:1415-1427.

5. Gu Y, Jerome F: Glycerol as a sustainable solvent for green chemistry. Green Chemistry 2010, 12:1127-1138.

6. Sheldon RA: Fundamentals of green chemistry: efficiency in reaction design. Chemical Society Reviews 2012, 41:1437-1451.

7. Li C-J, Trost BM: Green chemistry for chemical synthesis. Proceedings of the National Academy of Sciences 2008, 105:13197-13202.

8. Chen G-Q, Patel MK: Plastics derived from biological sources: present and future: a technical and environmental review. Chemical Reviews 2011, 112:2082-2099.

9. Bozell JJ, Petersen GR: Technology development for the production of biobased products from biorefinery carbohydrates-the US Department of Energy's "Top 10" revisited. Green Chemistry 2010, 12:539-554.

10. Vaccaro L, Lanari D, Marrocchi A, Strappaveccia G: Flow approaches towards sustainability. Green Chemistry 2014.

11. Newman SG, Jensen KF: The role of flow in green chemistry and engineering. Green Chemistry 2013, 15:1456-1472.

12. Moseley JD, Kappe CO: A critical assessment of the greenness and energy efficiency of microwave-assisted organic synthesis. Green Chemistry 2011, 13:794-806.

13. Anastas PTA, Warner JCA: Green Chemistry: Theory and Practice: Oxford University Press; 2000.

14. IEA: Chemical and Petrochemical Sector, Potential of Best Practice Technology and other Measures for Improving Energy Efficiency Edited by. France IEA; 2009.

15. Masanet E, Chang Y, Gopal AR, Larsen P, Morrow WR, Sathre R, Shehabi A, Zhai P: Life-Cycle Assessment of Electric Power Systems. Annual Review of Environment and Resources 2013, 38:107-136.

16. Sabine Brueske RS, Chris Zach, and Howard Andres: U.S. Manufacturing Energy Use and Greenhouse Gas Emissions Analysis. Edited by: Oak Ridge National Laboratory; 2012. vol ORNL/TM-2012/504.]

17. IPCC: Climate change 2014: impacts, adaptation, and vulnerability Edited by. Switzerland: IPCC; 2014. 
18. IEA, ICCA, DECHEMA: Technology Roadmap, Energy and GHG Reductions in the Chemical Industry via Catalytic Processes Edited by. France: IEA, ICCA, DECHEMA; 2013.

19. Neelis ML, Worrell E, Masanet E: Energy Efficiency Improvement and Cost Saving Opportunities for the Petrochemical Industry Edited by. Berkeley, CA, USA: Lawrence Berkeley National Laboratory 2008.

20. ENERGETICS: Chemicals Industry Updated Energy Bandwidth Study. Edited by: U.S. Department of Energy 2013.

21. Masanet E, Walker ME: Energy-water efficiency and U.S. industrial steam. AIChE Journal 2013, 59:2268-2274.

22. Wright AM, Michaela; Gemmer, Bob; Scheihing, Paul; and James Quinn.: Results from the U.S. DOE 2006 Save Energy Now Assessment Initiative. Edited by. Washington, DC: U.S. Department of Energy; 2007.

23. BASF: CAMOL ${ }^{\mathrm{TM}}$ Catalytic Coatings for Steam Cracker Furnace Tubes. Edited by. Canada BASF 2012.

24. Kookos IK: Optimal Design of Membrane/Distillation Column Hybrid Processes. Industrial \& Engineering Chemistry Research 2003, 42:1731-1738.

25. Bernardo P, Drioli E, Golemme G: Membrane Gas Separation: A Review/State of the Art. Industrial \& Engineering Chemistry Research 2009, 48:4638-4663.

26. Benali M, Aydin B: Ethane/ethylene and propane/propylene separation in hybrid membrane distillation systems: Optimization and economic analysis. Separation and Purification Technology 2010, 73:377-390.

27. Program SBIRS: Novel Membranes for Olefin/Paraffin Separation. Edited by; 2011.

28. Yang D, Le L, Martinez R, Morrison M: Hollow Fibers Structured Packings in Olefin/Paraffin Distillation: Apparatus Scale-Up and Long-Term Stability. Industrial \& Engineering Chemistry Research 2013, 52:9165-9179.

29. DOE: Enhanced Separation Efficiency in Olefin/Paraffin Distillation Edited by; 2008. vol 2013.]

30. Ren $\mathrm{T}$, Patel $\mathrm{M}$, Blok K: Olefins from conventional and heavy feedstocks: Energy use in steam cracking and alternative processes. Energy 2006, 31:425-451.

31. Cavani F, Ballarini N, Cericola A: Oxidative dehydrogenation of ethane and propane: How far from commercial implementation? Catalysis Today 2007, 127:113-131.

32. Ren T, Patel MK, Blok K: Steam cracking and methane to olefins: Energy use, CO2 emissions and production costs. Energy 2008, 33:817-833.

33. Chen JQ, Bozzano A, Glover B, Fuglerud T, Kvisle S: Recent advancements in ethylene and propylene production using the UOP/Hydro MTO process. Catalysis Today 2005, 106:103-107.

34. Agouram S, Dejoz A, Ivars F, Vázquez I, López Nieto JM, Solsona B: Oxidative dehydrogenation of ethane: A study over the structure and robustness of $\mathrm{Ni}-\mathrm{W}-\mathrm{O}$ catalysts. Fuel Processing Technology 2014, 119:105-113.

35. Arnold SC, Gaffney AM, Song R, Yeh CY: Process for producing ethylene via oxidative dehydrogenation (odh) of ethane. US Patent 2010.

36. Gärtner CA, van Veen AC, Lercher JA: Oxidative Dehydrogenation of Ethane: Common Principles and Mechanistic Aspects. ChemCatChem 2013, 5:3196-3217.

37. Intratec Solutions: Technology Economics: Propylene via Propane Dehydrogenation, Part 2: CreateSpace Independent Publishing Platform; 2013.

38. Horncastle A, Sastry A, Corrigan J, Gotpagar J: Future of Chemicals Rebalancing Global Feedstock Distruptions with " On-purpose" Technologies Edited by: Booz \& Company 2012. 
39. Appl M: Ammonia. In Ullmann's Encyclopedia of Industrial Chemistry, Electronic Releae Edited by: Wiley-VCH; 2010.

40. SmartKoncept Technology: Final scientific technical report: ammonia process by pressure swing adsorption. Edited by. Houston, TX, USA 2010.

41. Alvarez-Galvan MC, Mota N, Ojeda M, Rojas S, Navarro RM, Fierro JLG: Direct methane conversion routes to chemicals and fuels. Catalysis Today 2011, 171:15-23.

42. Shan J-j, Huang W, Nguyen L, Yu Y, Zhang S, Li Y, Frenkel Al, Tao F: Conversion of methane to methanol with a bent mono( $\mu$-oxo)dinickel anchored on internal surface of micropores. Langmuir 2014.

43. Hammond C, Forde MM, Ab Rahim MH, Thetford A, He Q, Jenkins RL, Dimitratos N, LopezSanchez JA, Dummer NF, Murphy DM, et al.: Direct catalytic conversion of methane to methanol in an aqueous medium by using copper-promoted Fe-ZSM-5. Angewandte Chemie International Edition 2012, 51:5129-5133.

44. Li T, Wang SJ, Yu CS, Ma YC, Li KL, Lin LW: Direct conversion of methane to methanol over nano-[Au/SiO2] in [Bmim]Cl ionic liquid. Applied Catalysis A: General 2011, 398:150154.

45. Zhang J, Burklé-Vitzthum V, Marquaire PM, Wild G, Commenge JM: Direct conversion of methane in formaldehyde at very short residence time. Chemical Engineering Science 2011, 66:6331-6340.

46. Wang Z-C, Dietl N, Kretschmer R, Ma J-B, Weiske T, Schlangen M, Schwarz H: Direct Conversion of methane into formaldehyde mediated by [Al203].+ at room temperature. Angewandte Chemie International Edition 2012, 51:3703-3707.

47. Phan A, Czaja AU, Gándara F, Knobler CB, Yaghi OM: Metal-organic frameworks of vanadium as catalysts for conversion of methane to acetic acid. Inorganic Chemistry 2011, 50:7388-7390.

48. Guo X, Fang G, Li G, Ma H, Fan H, Yu L, Ma C, Wu X, Deng D, Wei M, et al.: Direct, nonoxidative conversion of methane to ethylene, aromatics, and hydrogen. Science 2014, 344:616-619.

49. Fanelli M, Arora R, Tonkovich A, Marco J, Rode E: Advanced distillation final report Edited by. Plain City, OH, USA: DOE; 2010.

50. Yang D, Martinez R, Fayyaz-Najafi B, Wright R: Light hydrocarbon distillation using hollow fibers as structured packings. Journal of Membrane Science 2010, 362:86-96.

51. Haldor Topsøe: Topsøe's Ammonia Technology Today. Edited by: Haldor Topsoe; 2013.

52. Rice SF, Mann DP: Autothermal reforming of natural gas to synthesis gas. Edited by. Livermore, CA, USA Sandia National Laboratories; 2007.

53. Martin N, Worrell E, Ruth M, Price L, Elliot RN, Shipley AM, Thorne J: Emerging energyefficient industrial technologies. Edited by: Lawrence Berkeley National Laboratory 2000.

54. Singh S, Price J: KRES-ES ${ }^{\mathrm{TM}}$ revamp makes more ammonia from less natural gas by energy substitution. In Nitrogen + Syngas International Conference \& Exhibition Edited by. Düsseldorf, Germany; 2011.

55. DOE: Grand Challenge Portfolio: Driving Innovations in Industrial Energy Efficiency Edited by. Washington, DC, USA: DOE; 2011.

56. ENERGETICS, DOE: Energy and environemental profile of the U.S. chemical industry Edited by. Columbia, Maryland 2000.

57. Worrell E, Phylipsen D, Einstein D, Martin N: Energy Use and Energy Intensity of the U.S. Chemical Industry Edited by. Berkeley, California: Ernest Orlando Lawrence Berkeley National Laboratory; 2000. 
58. Energy USDo: Manufacturing Energy Consumption Survey. Edited by. Washington, DC.; 2013.

59. Rebitzer G, Ekvall T, Frischknecht R, Hunkeler D, Norris G, Rydberg T, Schmidt WP, Suh S, Weidema BP, Pennington DW: Life cycle assessment: Part 1: Framework, goal and scope definition, inventory analysis, and applications. Environment International 2004, 30:701-720.

60. Menon V, Rao M: Trends in bioconversion of lignocellulose: biofuels, platform chemicals \& biorefinery concept. Progress in Energy and Combustion Science 2012, 38:522-550.

61. Balat M: Production of bioethanol from lignocellulosic materials via the biochemical pathway: A review. Energy Conversion and Management 2011, 52:858-875.

62. Bioenergy I: Bio-based chemicals - value added products from biorefineries. Edited by. The Netherlands; 2012.

63. Clark JH, Luque R, Matharu AS: Green chemistry, biofuels, and biorefinery. Annual Review of Chemical and Biomolecular Engineering 2012, 3:183-207.

64. Cherubini F, Jungmeier G: LCA of a biorefinery concept producing bioethanol, bioenergy, and chemicals from switchgrass. The International Journal of Life Cycle Assessment 2010, 15:53-66.

65. Kajaste R: Chemicals from biomass - managing greenhouse gas emissions in biorefinery production chains - a review. Journal of Cleaner Production 2014, 75:1-10.

66. Cherubini $F$, Ulgiati S: Crop residues as raw materials for biorefinery systems - A LCA case study. Applied Energy 2010, 87:47-57.

67. Patel MK, Crank M, Dornburg V, Hermann B, Roes L: Medium and long-term opportunities and risks of the biotechnological production of bulk chemicals from renewable resources Edited by. Netherlands Utrecht University 2006.

68. Chen G-Q: A microbial polyhydroxyalkanoates (PHA) based bio- and materials industry. Chemical Society Reviews 2009, 38:2434-2446.

69. Boussie T: Scale-Up and Commercialization of Bio-Based Adipic Acid and HMD Edited by; 2013. vol 2014.]

70. Harrington R: Coca-Cola Targets 100\% Plant-based Bottle by 2017. Edited by; 2011.

71. IEA-ETSAP, IRENA Technology: Production of bio-ethylene Edited by: IEA-ETSAP and IRENA Technology 2013.

72. Peters M, Köhler B, Kuckshinrichs W, Leitner W, Markewitz P, Müller TE: Chemical technologies for exploiting and recycling carbon dioxide into the value chain. ChemSusChem 2011, 4:1216-1240.

73. Olah GA: Towards oil independence through renewable methanol chemistry. Angewandte Chemie International Edition 2013, 52:104-107.

74. Russell C: Barriers to Industrial Energy Cost Control: The Competitor Within. Chemical Processing 2005, June 8th.

75. van Duuren JBJH, Brehmer B, Mars AE, Eggink G, dos Santos VAPM, Sanders JPM: A limited LCA of bio-adipic acid: manufacturing the nylon-6,6 precursor adipic acid using the benzoic acid degradation pathway from different feedstocks. Biotechnology and Bioengineering 2011, 108:1298-1306.

76. Crank M, Marscheider-Weidemann F, Schleich J, Hüsing B, Angerer G: Techno-economic feasibility of large-scale production of bio-based polymers in Europe. Edited by Wolf $O$. Spain: DG JRC; 2005.

77. Saygin D, Gielen DJ, Draeck M, Worrell E, Patel MK: Assessment of the technical and economic potentials of biomass use for the production of steam, chemicals and polymers. Renewable and Sustainable Energy Reviews 2014, 40:1153-1167. 
78. Shen L, Worrell E, Patel MK: Comparing life cycle energy and GHG emissions of bio-based PET, recycled PET, PLA, and man-made cellulosics. Biofuels, Bioproducts and Biorefining 2012, 6:625-639.

79. Kim J, Henao CA, Johnson TA, Dedrick DE, Miller JE, Stechel EB, Maravelias CT: Methanol production from $\mathrm{CO} 2$ using solar-thermal energy: process development and technoeconomic analysis. Energy \& Environmental Science 2011, 4:3122-3132.

80. von der Assen N, Jung J, Bardow A: Life-cycle assessment of carbon dioxide capture and utilization: avoiding the pitfalls. Energy \& Environmental Science 2013, 6:2721-2734. 